\title{
2 Coevolution of the olfactory organ and its receptor repertoire in ray-finned
}

3 fishes

4

5 Maxime Policarpo ${ }^{1 \$}$, Katherine E Bemis ${ }^{2 \$}$, Patrick Laurenti ${ }^{3}$, Laurent Legendre ${ }^{1}$, Jean-

6 Christophe Sandoz ${ }^{1}$, Sylvie Rétaux ${ }^{*}, 4$ and Didier Casane ${ }^{*}, 1,5$

7

$8 \quad{ }^{1}$ Université Paris-Saclay, CNRS, IRD, UMR Évolution, Génomes, Comportement et

9 Écologie, 91198, Gif-sur-Yvette, France.

$10{ }^{2}$ NOAA National Systematics Laboratory, National Museum of Natural History, Smithsonian

11 Institution, Washington, D.C. 20560, U.S.A.

$12{ }^{3}$ Université de Paris, Laboratoire Interdisciplinaire des Energies de Demain, Paris, France

13 4 Université Paris-Saclay, CNRS, Institut des Neurosciences Paris-Saclay, 91400 Saclay,

14 France.

$15 \quad{ }^{5}$ Université de Paris, UFR Sciences du Vivant, F-75013 Paris, France.

16

17 \$: participated equally to this work

18 * : Corresponding author: e-mail: didier.casane@egce.cnrs-gif.fr, sylvie.retaux@cnrs.fr 


\section{Abstract}

23 Ray-finned fishes (Actinopterygii) perceive their environment through a range of sensory modalities, including olfaction ${ }^{1,2}$. Anatomical diversity of the olfactory organ suggests that olfaction is differentially important among species ${ }^{1,3,4}$. To explore this topic, we studied the evolutionary dynamics of the four main gene families (OR, TAAR, ORA/VR1 and OlfC/VR2) ${ }^{5}$ coding for olfactory receptors in 185 species of ray-finned fishes. The large variation in the number of functional genes, between 28 in the Ocean Sunfish Mola mola and 1317 in the Reedfish Erpetoichthys calabaricus, is the result of parallel expansions and contractions of the four main gene families. Several ancient and independent simplifications of the olfactory organ are associated with massive gene losses. In contrast, polypteriforms, which have a unique and complex olfactory organ, have almost twice as many olfactory receptor genes as any other ray-finned fish. These observations suggest a functional link between morphology of the olfactory organ and richness of the olfactory receptor repertoire. fishes is heterogeneous and presents a dynamic pattern of evolutionary expansions, simplifications and reacquisitions. gene family dynamics. 


\section{Introduction}

With more than 34,000 valid species, Actinopterygii (ray-finned fishes) is the largest group of aquatic vertebrates ${ }^{6}$. Most species of ray-finned fishes belong to Teleostei (teleosts), but a few extant species belong to relictual clades: Polypteriformes, Acipenseriformes,

Lepisosteiformes and Amiiformes (Fig. 1). With a last common ancestor that lived 368-379

Million years ago (Ma) ${ }^{7,8}$, the remarkable taxonomic diversity of actinopterygians comes with striking anatomical, physiological, behavioral and ecological adaptations ${ }^{9}$.

Actinopterygians thrive in aquatic habitats from the tropics to the polar regions, in small temporary ponds to large oceans.

Ray-finned fishes have several sensory systems to process physical and chemical cues. Among them, the olfactory system serves in feeding, reproduction, predator avoidance and migration ${ }^{10}$. In a seminal work, Burne $(1909)^{3}$ described the great anatomical diversity in the olfactory organs of ray-finned fishes. Since then, it has been assumed that fishes with a multilamellar olfactory epithelium have a better sense of smell than those with a flat olfactory epithelium, respectively classified as macrosmatic and microsmatic ${ }^{11}$.

In most ray-finned fishes, the olfactory epithelium forms a rosette in which lamellae attach to a central raphe (e.g., Danio rerio in Fig. 2A). Chondrichthyans (sharks, rays, chimaeras) also have olfactory rosettes ${ }^{12}$, thus it is likely that olfactory rosettes were present in the common ancestor of jawed vertebrates and conserved in the common ancestor of ray-finned fishes.

However, the olfactory rosette has been simplified several times during the evolution of rayfinned fishes, leading in the most extreme cases to a small, flat olfactory epithelium with no lamellae (e.g., Syngnathus typhle in Fig. 2A) ${ }^{4,13}$. In contrast, other groups have multilamellar organizations of the olfactory epithelium. The most extreme example of a multilamellar olfactory epithelium occurs in the Polypteriformes, which have a large and complex structure: 
a nasal capsule is divided into six sectors, five in a main sac and one in a diverticulum, each with a rosette-like organization with a septum and lamellae attached to both sides (e.g., Polypterus senegalus and Erpetoichthys calabaricus in Fig. 2A) ${ }^{14,15}$.

The diversity of odorants that can be detected depends on the size of the olfactory receptor gene repertoire ${ }^{16}$. In vertebrates, olfactory receptor genes belong to four main gene families with independent origins: odorant receptors (OR), trace amine-associated receptors (TAAR), and vomeronasal receptors 1 and 2 (named VR1 and VR2 in tetrapods). Actinopterygian fishes do not have a vomeronasal organ, and thus VR1 and VR2 gene families are referred to as ORA and OlfC, respectively. Only a few olfactory receptor genes have been identified that do not belong to these four gene families ${ }^{17}$.

Analyses of genomes of 13 teleosts and one non-teleost suggested that ORA is a small and stable gene family, with eight genes in the last common ancestor of ray-finned fishes and six genes in most teleosts ${ }^{18}$. More genes have been identified in OR, TAAR and OlfC gene families ${ }^{19-21}$, but only the evolutionary dynamics of OR genes have been analyzed broadly in teleosts ${ }^{13}$. Policarpo et al. $(2021)^{13}$ found a $~ 30$-fold variation in the number of OR genes (15 in Ocean Sunfish Mola mola and Broad-nose Pipefish Syngnathus typhle to 429 in Zig-zag Eel Mastacembelus armatus) and reported that the number of olfactory lamellae correlates with the richness of the OR gene repertoire.

A recent burst of high quality ray-finned fish genomes, in particular for non-teleost actinopterygians such as polypteriforms, prompted us to analyze the evolution the four olfactory gene families and the anatomy of the olfactory organ across the phylogeny of rayfinned fishes. 


\section{Coevolutionary dynamics of olfactory gene families}

93

We characterized the olfactory receptor gene repertoire, including OR, TAAR, OlfC and ORA genes, for 185 species of ray-finned fishes selected on the basis of high genome completeness

(Fig. 1, Extended Data Fig. 1 and Supplementary data 1).

The mean size of the total olfactory gene repertoire for actinopterygians was 224 genes. The largest (1317 genes) was found in the polypteriform Erpetoichthys calabaricus (Reedfish) and the smallest (28 genes) in the tetraodontiform Mola mola (Ocean Sunfish) (Fig. 1).

ORA is a small and stable family typically comprising six genes (ORA1 to ORA6) in teleosts ${ }^{18}$. Nevertheless, we found up to three ORA genes have been lost in several lineages, and, surprisingly, this gene family is much larger in some lineages, particularly polypteriforms, which have nearly 50 functional ORA genes (Fig. 1 and Extended Data Fig. 1A). Two genes, ORA7 and ORA8, were present in the last common ancestor of ray-finned fishes; ORA7 was lost in the common ancestor of teleosts, while ORA8 was lost in clupeocephalans (Extended Data Fig. 2).

The evolution of the other three gene families (OR, TAAR, OlfC) has been more dynamic. For example, we identified an average of 126 functional OR genes in ray-finned fishes, but the variance is large, with 623 and 606 OR genes in the polypteriforms Erpetoichthys calabaricus and Polypterus senegalus, respectively, and only 15 OR genes in the Ocean Sunfish Mola mola and Broad-nose Pipefish Syngnathus typhle (Fig. 1 and Extended Data

Fig. 1B). The OR family is split into seven monophyletic subfamilies, $\alpha, \beta, \gamma, \delta, \varepsilon, \xi$ and $\eta^{22}$. In tetrapods, $\alpha$ and $\gamma$ families expanded and other subfamilies are relictual or absent. In contrast, in teleosts the $\alpha$ family is absent and only one copy of a $\gamma$ family gene occurs in Zebrafish Danio rerio ${ }^{22}$. Our analysis shows that $\alpha$ family genes occur in all non-teleost actinopterygians, but that the $\alpha$ family was lost in the common ancestor of teleosts (Extended 
117 Data Fig. 1B ). The $\gamma$ family is well represented in non-teleost actinopterygians whereas only

118 a few copies are scattered in the teleost phylogeny (Extended Data Fig. 1B). This suggests

119 that the $\gamma$ family was present in the common ancestor of teleosts but lost in most teleost

120 lineages.

121 The number of genes in the TAAR and OlfC repertoires is smaller than in the OR repertoire,

122 with an average of 51 and 40 genes per species, respectively. For these two gene families, the

123 variance is also large. For example, the polypteriform Erpetoichthys calabaricus has 486

124 TAAR and 161 OlfC genes. At the opposite extreme, only three TAAR genes were found in

125 the syngnathiform Callionymus lyra and two OlfC genes in tetraodontiform Mola mola (Fig.

1261 and Extended Data Fig. 1C,D).

127 To analyze the evolutionary dynamics of the olfactory receptor gene families, we computed

128 birth and death rates along branches of the phylogeny for OR, TAAR and OlfC families using

129 the gene tree - species tree reconciliation method ${ }^{23}$. The mean birth and death rates were

130 similar in OR, TAAR and OlfC families, 0.0071/0.0071, 0.0101/0.0079 and 0.0059/0.0069

131 per gene per million years, respectively (Extended Data Fig. 3). Whereas birth and death

132 rates are similar along most branches, we observed concomitant high death rates of OR,

133 TAAR and OlfC genes in the common ancestor of two sampled species of Siluriformes

134 (Bagarius yarrelli and Tachysurus fulvidraco), in the common ancestor of Lophiiformes and

135 Tetraodontiformes, and in the common ancestor of Kurtiformes and Syngnathiformes. We

136 also observed concomitant high birth rates of OR, TAAR and OlfC genes in the common

137 ancestor of Labriformes and Cyprinodontiformes, and in the common ancestor of Perca +

138 Sander (Fig. 1, Extended Data Fig. 3).

139 Despite variation in the number of genes in a family, we did not find evidence that contraction

140 of one gene family is compensated by expansion of others. On the contrary, there is a

141 correlation between the number of functional genes in each family (phylogenetic generalized 
142 least squares (PGLS); $\mathrm{R}^{2}=0.50$ between OR and TAAR, $\mathrm{R}^{2}=0.56$ between OR and OlfC, $\mathrm{R}^{2}$

$143=0.40$ between TAAR and OlfC, all p-values $<2$ e-16, Fig. 3 ).

144 Moreover, in most species, the number of OR genes is greater than the number of TAAR or

145 OlfC genes, and often the number of TAAR genes is greater than the number of OlfC genes

146 (Fig. 3).

147 Although the number of ORA genes is less dynamic, particularly in teleosts, species with a

148 high number of OR, TAAR and OlfC genes, such as Polypteriformes or Anguilliformes, tend

149 to have more ORA genes, whereas species with few genes in these three families, such as

150 Mola mola, tend to have fewer ORA genes (Fig. 1).

151 The coevolution of the three dynamic receptor gene families (OR, TAAR, OlfC) is also

152 supported by the correlation between the number of gene losses along the branches of the

153 phylogenetic tree (Pearson's $r=0.8$ between OR and TAAR, 0.52 between OR and OlfC and

1540.62 between TAAR and OlfC, all p-values $<2 \mathrm{e}-16)$ and gene gains $(\mathrm{r}=0.79$ between OR

155 and TAAR, 0.78 between OR and OlfC and 0.69 between TAAR and OlfC, all p-values $<2$ e-

156 16) (Extended Data Fig. 4).

157 The coevolution of the OR, TAAR and OlfC receptor gene families is further supported by a

158 correlation of the number and proportion of pseudogenes, which agrees with similar gene

159 death rates in the three dynamic gene families (Extended data Fig. 5).

160 Together, these results suggest that dramatic changes in evolutionary constraints on the size of

161 the olfactory repertoire occurred several times, with periods of expansion or contraction

162 affecting OR, TAAR and OlfC olfactory receptor families the same way. Hence, they

163 constitute a single evolutionary unit in ray-finned fishes. 
Using data for 72 species of ray-finned fishes (Supplementary data 1), we confirmed the correlation between the number of OR genes and the number of lamellae in the olfactory organ (PGLS; $\mathrm{R}^{2}=0.57, \mathrm{p}=1.38 \mathrm{e}-14$, Fig. 4A) reported recently for a smaller sample of 35 teleosts and two non-teleost ray-finned fishes ${ }^{13}$. While no significant correlation was found between the number of lamellae and the number of TAAR genes (PGLS; $\mathrm{R}^{2}=0.00177, \mathrm{p}=$ 0.726, Fig. 4B), a correlation was found with the number of OlfC genes (PGLS; $\mathrm{R}^{2}=0.21$, $\mathrm{P}$

$173=4.55 \mathrm{e}-05$, Fig. 4C) and the total number of olfactory receptor genes (PGLS; $\mathrm{R}^{2}=0.13, \mathrm{p}=$ 0.00176, Fig. 4D).

The smallest olfactory repertoires occur in Ocean Sunfish Mola mola (28 genes) and Broadnosed Pipefish Syngnathus typhle (35 genes). These extreme reductions of olfactory receptor diversity evolved independently and in parallel with the simplification of the olfactory organ, which is a small, flat olfactory epithelium in both species ${ }^{13,24}$ (Fig. 2A). Moreover, M. mola has greatly reduced olfactory nerves and reduced olfactory bulbs ${ }^{25}$.

At the other extreme is the unique organization of the olfactory organ of polypteriforms. In both species studied, the olfactory organ consists of six sectors, each with a rosette-like structure ${ }^{14,15}$, resulting in many more olfactory lamellae than any other ray-finned fishes (Fig.

183 2A). Polypteriforms also have a much larger olfactory gene repertoire with many more genes in all four gene families than in any other ray-finned fishes (Polypterus senegalus: 1237 olfactory receptors, 300 olfactory lamellae; Erpetoichthys calabaricus: 1317 olfactory receptors, 150 olfactory lamellae; Fig. 1). The two other species studied that had the most

187 olfactory receptor genes also had many olfactory lamellae (Anguilla anguilla: 658 olfactory

188 receptors and 99 olfactory lamellae; Mastacembelus armatus: 677 olfactory receptors, 68

189 olfactory lamellae; Fig. 1). Interestingly, P. senegalus, E. calabaricus, A. anguilla and M.

190 armatus are nocturnal (e.g., ${ }^{26,27}$ ), perhaps making them more reliant on olfaction. They also

191 have other specializations of the olfactory system, such as prominent, anteriorly directed 
192

193

194

195

incurrent narial tubes (Extended data Fig. 6). Such tubes direct water flow into the olfactory organ and allow the fish to sample water away from its boundary layer ${ }^{28}$.

After an extreme contraction of the olfactory gene repertoire and simplification of the olfactory epithelium, a secondary expansion in the gene repertoire occurred in parallel with the reacquisition of a multilamellar epithelium in the tetraodontiform genus Takifugu. The genomes of Takifugu rubripes, T. flavidus, and T. bimaculatus have more olfactory genes (156, 124 and 140 respectively) than in other tetraodontiforms with a flat olfactory epithelium, Dichotomyctere nigroviridis (70 genes) and Mola mola (28 genes). The increased number of genes in the three species of Takifugu is due to duplications of OR, TAAR and OlfC genes (Extended data Fig. 1B-D). We dissected a specimen of T. rubripes and found a non-rosette, but multilamellar, organization of parallel lamellae on the floor of the olfactory chamber that continues on the ventral surface of the nasal bridge between the incurrent and excurrent nares (Extended data Fig. 7). This novel organization supports the hypothesis of a reacquisition of a multilamellar olfactory epithelium in association with secondary expansion of the olfactory receptor gene repertoire.

Together, our results indicate a functional link between receptor diversity and the number of lamellae in the olfactory organ of ray-finned fishes (Fig. 2B). In the most extreme cases, this leads to the loss of the rosette (e.g., Mola mola and Syngnathus typhle) or anatomical innovations with several rosettes (e.g., polypteriforms) or a novel organization of olfactory lamellae (e.g., species of Takifugu). This link limits the morpho-genomic space occupied by ray-finned fishes (Fig. 2B). Accordingly, we did not observe ray-finned fishes with many olfactory genes and few olfactory lamellae or fishes with few olfactory genes and many olfactory lamellae (Figs. 2, 4). Because a large number of olfactory neurons expressing each olfactory receptor is necessary for an efficient olfaction, there is a functional limit to the number of olfactory receptor genes that can be expressed on a given area of olfactory 
epithelium. This would explain why there are no species with many olfactory receptor genes

218 and few olfactory lamellae. We did not find any examples of macrosmatic fishes with a low number of olfactory receptor genes, which would favor high sensitivity for a small set of

221 specialization, and perhaps cartilaginous fishes, which have few olfactory receptor genes and 222 large multilamellar olfactory organs ${ }^{29}$, may occupy this area of the morpho-genomic space.

\section{Conclusion}

Our analysis of 185 high quality genomes of ray-finned fishes highlights the diversity of the olfactory receptor repertoire. The number of genes is highly dynamic for three (OR, TAAR, OlfC) of the four gene families, but the reasons for large gene gains or losses are still unknown. In marine tetrapods, including cetaceans and sea snakes, extreme reductions in the number of olfactory genes occurred likely because air-adapted olfactory systems were not useful in marine environments ${ }^{30}$. No such major ecological transition is associated with gene losses of similar magnitude in Syngnathiformes and Tetraodontiformes, and it remains unknown why their olfaction degenerated at both morphological and genomic levels. The

234 complexity of the olfactory organ and large olfactory gene repertoire in Polypteriformes is

235 also surprising. To date, few olfactory receptor genes have been de-orphanized, and such 236 functional information, combined with behavioral studies, may shed light on the dynamics of 237 losses and specializations. Together, our analyses of the olfactory gene repertoire and 238 morphology of the olfactory epithelium show that olfaction is a heterogeneous sensory 239 modality in ray-finned fishes. Our identification of non-model species with particularly poorly 240 developed olfaction (e.g., Mola mola) or exceptionally well-developed sense of smell (e.g., 
bioRxiv preprint doi: https://doi.org/10.1101/2021.12.13.472396; this version posted December $14,2021$. The copyright holder for this

preprint (which was not certified by peer review) is the author/funder, who has granted bioRxiv a license to display the preprint in perpetuity. It is made available under aCC-BY 4.0 International license.

241 Erpetoichthys calabaricus) opens new possibilities for comparative and functional research

242 on olfaction.

243 


\section{4}

\section{Main references}

2461 Kasumyan, A. The olfactory system in fish: structure, function, and role in behavior. Journal

of Ichthyology 44, S180-S223 (2004).

2 Yoshihara, Y. Zebrafish olfactory system. In The Olfactory System (ed K. Mori) Springer, 7196 (2014).

Burne, R. H. The anatomy of the olfactory organ of teleostean fishes. Proceedings of the Zoological Society of London 2, 610-663 (1909).

Hansen, A. \& Zielinski, B. S. Diversity in the olfactory epithelium of bony fishes: development, lamellar arrangement, sensory neuron cell types and transduction components. Journal of Neurocytology 34, 183-208 (2005).

Nei, M., Niimura, Y. \& Nozawa, M. The evolution of animal chemosensory receptor gene repertoires: roles of chance and necessity. Nature Reviews Genetics 9, 951-963 (2008).

Fricke, R., Eschmeyer, W. N. \& Van der Laan, R. Eschmeyer's Catalog of Fishes: Genera, species, references.

(http://researcharchive.calacademy.org/research/ichthyology/catalog/fishcatmain.asp). Electronic version accessed 16 October 2021. (2021).

Rabosky, D. L. et al. An inverse latitudinal gradient in speciation rate for marine fishes. Nature 559, 392-395 (2018).

Hughes, L. C. et al. Comprehensive phylogeny of ray-finned fishes (Actinopterygii) based on transcriptomic and genomic data. Proceedings of the National Academy of Sciences USA 115, 6249-6254 (2018).

Helfman, G., Collette, B. B., Facey, D. E. \& Bowen, B. W. The Diversity of Fishes: Biology, Evolution, and Ecology. (Wiley-Blackwell, 2009).

Hara, T. J. Olfaction in fish. Progress in Neurobiology 5, 271-335 (1975).

Teichmann, H. Vergleichende untersuchungen an der nase der fische. Zeitschrift für Morphologie und Ökologie der Tiere 43, 171-212 (1954). 
$271 \quad 12$ Ferrando, S. et al. Clarification of the terminology of the olfactory lamellae in

272 Chondrichthyes. The Anatomical Record 300, 2039-2045 (2017).

27313 Policarpo, M. et al. Evolutionary dynamics of the OR gene repertoire in teleost fishes: evidence of an association with changes in olfactory epithelium shape. Molecular Biology and Evolution 38, 3742-3753 (2021).

$27614 \quad$ Pfeiffer, W. Das geruchsorgan der Polypteridae (Pisces, Brachiopterygii). Z. Morph. Tiere 63, $277 \quad 75-110(1968)$.

27815 Theisen, B. The morphology and vascularization of the olfactory organ in Calamoichthys 279 calabaricus (Pisces, Polypteridae). Vidensk. Meddr dansk naturh. Foren. 133, 31-50 (1970).

28016 Buck, L. \& Axel, R. A novel multigene family may encode odorant receptors: a molecular 281 basis for odor recognition. Cell 65, 175-187 (1991).

28217 Kowatschew, D. \& Korsching, S. I. An ancient adenosine receptor gains olfactory function in 283 bony vertebrates. Genome Biology and Evolution 13, evab211 (2021).

$28418 \quad$ Zapilko, V. \& Korsching, S. I. Tetrapod V1R-like ora genes in an early-diverging ray-finned 285 fish species: the canonical six ora gene repertoire of teleost fish resulted from gene loss in a larger ancestral repertoire. BMC Genomics 17, 83 (2016). Yang, L. et al. Expansion of vomeronasal receptor genes (OlfC) in the evolution of fright reaction in Ostariophysan fishes. Communications Biology 2, 235 (2019). amblycephala) genome reveals an expansion of olfactory receptor genes in freshwater fish. Molecular Biology and Evolution 38, 4238-4251 (2021).

29221 Hussain, A., Saraiva, L. R. \& Korsching, S. I. Positive Darwinian selection and the birth of an olfactory receptor clade in teleosts. Proceedings of the National Academy of Sciences 106, 4313-4318 (2009).

29522 Niimura, Y. On the origin and evolution of vertebrate olfactory receptor genes: comparative genome analysis among 23 chordate species. Genome Biology and Evolution 1, 34-44 (2009).

29723 Comte, N. et al. Treerecs: an integrated phylogenetic tool, from sequences to reconciliations. Bioinformatics 36, 4822-4824 (2020). 
29924 Dymek, J. et al. Micro- and macro-morphology of the olfactory organ of Syngnathus typhle 300 (Syngnathidae, Actinopterygii). Acta Zoologica 102, 206-219 (2021).

30125 Burr, H. S. The central nervous system of Orthagoriscus mola. Journal of Comparative $302 \quad$ Neurology 45, 33-128 (1928).

$30326 \quad$ Znotinas, K. R. \& Standen, E. M. Aerial and aquatic visual acuity of the grey bichir

$304 \quad$ Polypterus senegalus, as estimated by optokinetic response. Journal of Fish Biology 95, 263-

$305 \quad 273(2019)$.

30627 LaBar, G. W., Hernando Casal, J. A. \& Delgado, C. F. Local movements and population size 307 of European eels, Anguilla anguilla, in a small lake in southwestern Spain. Environmental 308 Biology of Fishes 19, 111-117 (1987).

30928 Cox, J. P. L. Hydrodynamic aspects of fish olfaction. Journal of The Royal Society Interface $310 \quad 5,575-593(2008)$.

31129 Sharma, K., Syed, A. S., Ferrando, S., Mazan, S. \& Korsching, S. I. The chemosensory 312 receptor Repertoire of a true shark is dominated by a single olfactory receptor family. Genome 313 Biology and Evolution 11, 398-405 (2019).

31430 Kishida, T. Olfaction of aquatic amniotes. Cell and tissue research 383, 353-365 (2021). 315 


\section{Main figures legends}

320 Fig. 1. Diversity of olfactory receptor gene repertoire in ray-finned fishes (Actinopterygii).

321 Time-calibrated phylogeny from https://fishtreeoflife.org/. For each species, a barplot

322 represents the number of OR, TAAR, OlfC and ORA genes. Where available, number of

323 olfactory lamellae is indicated. Branches associated with two highest birth rates and two

324 highest death rates are indicated by diamond and oval symbols, respectively. Branch color

325 code: Polypteriformes (red, Polypterus senegalus; brown Erpetoichthys calabaricus);

326 Acipenseriformes (light blue Polyodon spathula; dark blue Acipenser ruthenus); Amiiformes

327 (yellow Amia calva); Lepisosteiformes (dark green Atractosteus spatula; light green

328 Lepisosteus oculatus); teleost (black). The phylogeny was visualized using iTOL. Distribution

329 of the total number of olfactory receptor genes per species is shown in center of figure.

331 Fig. 2. Morpho-genomic space of olfaction in ray-finned fishes. (A) Diversity of olfactory 332 organ morphology. Syngnathus typhle, 283 mm TL, Mola mola, $1290 \mathrm{~cm}$ TL, Takifugu 333 rubripes $290 \mathrm{~mm}$ TL, Danio rerio, $30 \mathrm{~mm}$ TL, Anguilla anguilla, $450 \mathrm{~mm}$ TL, Erpetoichthys 334 calabaricus, $268 \mathrm{~mm}$ TL, Polypterus senegalus, $112 \mathrm{~mm}$ TL. Anterior to left. (B) Correlation 335 between number of olfactory lamellae and number of olfactory receptor genes; all fishes 336 examined, ranging from microsmatic to macrosomatic, occurred in the blue region of the 337 graph. Most evolutionary transitions in the olfactory organ, indicated by arrows, were 338 simplifications (e.g., S. typhle, M. mola), but expansions (e.g., A. anguilla, E. calabaricus, and P. senegalus) and reacquisition (e.g., T. rubripes) also occurred. 
343 Fig. 3. Coevolution of number of OR, TAAR and OlfC genes in ray-finned fishes.

344 (A) OR and TAAR families. (B) OR and OlfC families. (C) TAAR and OlfC families.

345 Coefficient of determination $\left(\mathrm{R}^{2}\right)$, $\mathrm{p}$-value $(\mathrm{P})$ and regression line (solid line) of PGLS

346 analyses are reported. Dashed line shows slope $=1$. Dot color code: red, Polypterus

347 senegalus; brown Erpetoichthys calabaricus; light blue Polyodon spathula; dark blue

348 Acipenser ruthenus; yellow Amia calva; dark green Atractosteus spatula; light green

349 Lepisosteus oculatus; black (teleost).

350

351 Fig. 4. Coevolution of the olfactory gene repertoire and number of olfactory lamellae.

352 (A) OR genes. (B) TAAR genes. (C) OlfC genes. (D) Total olfactory receptor genes.

353 The coefficient of determination $\left(\mathrm{R}^{2}\right)$, the $\mathrm{p}$-value $(\mathrm{P})$ and regression line (solid line) of PGLS

354 analyses are reported. Dot color code: Polypteriformes (red, Polypterus senegalus; brown

355 Erpetoichthys calabaricus); Acipenseriformes (light blue Polyodon spathula; dark blue

356 Acipenser ruthenus); Amiiformes (yellow Amia calva); Lepisosteiformes (dark green

357 Atractosteus spatula; light green Lepisosteus oculatus); teleost (black). 
A. Anatomy of olfactory organs showing organization of lamellae

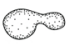

$0 . \overline{2 \mathrm{~mm}}$

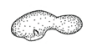

$\overline{5 \mathrm{~mm}}$

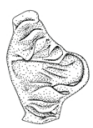

$\overline{2 \mathrm{~mm}}$

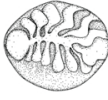

$\overline{1 \mathrm{~mm}}$

Syngnathus typhle

Takifugu rubripes

Danio rerio

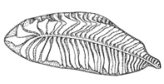

$\overline{1 \mathrm{~mm}}$

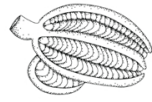

$1 \mathrm{~mm}$

Anguilla anguilla

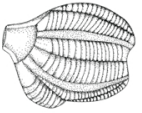

$3 \mathrm{~mm}$

Polypterus senegalus

B. Morpho-genomic space of olfaction in ray-finned fishes

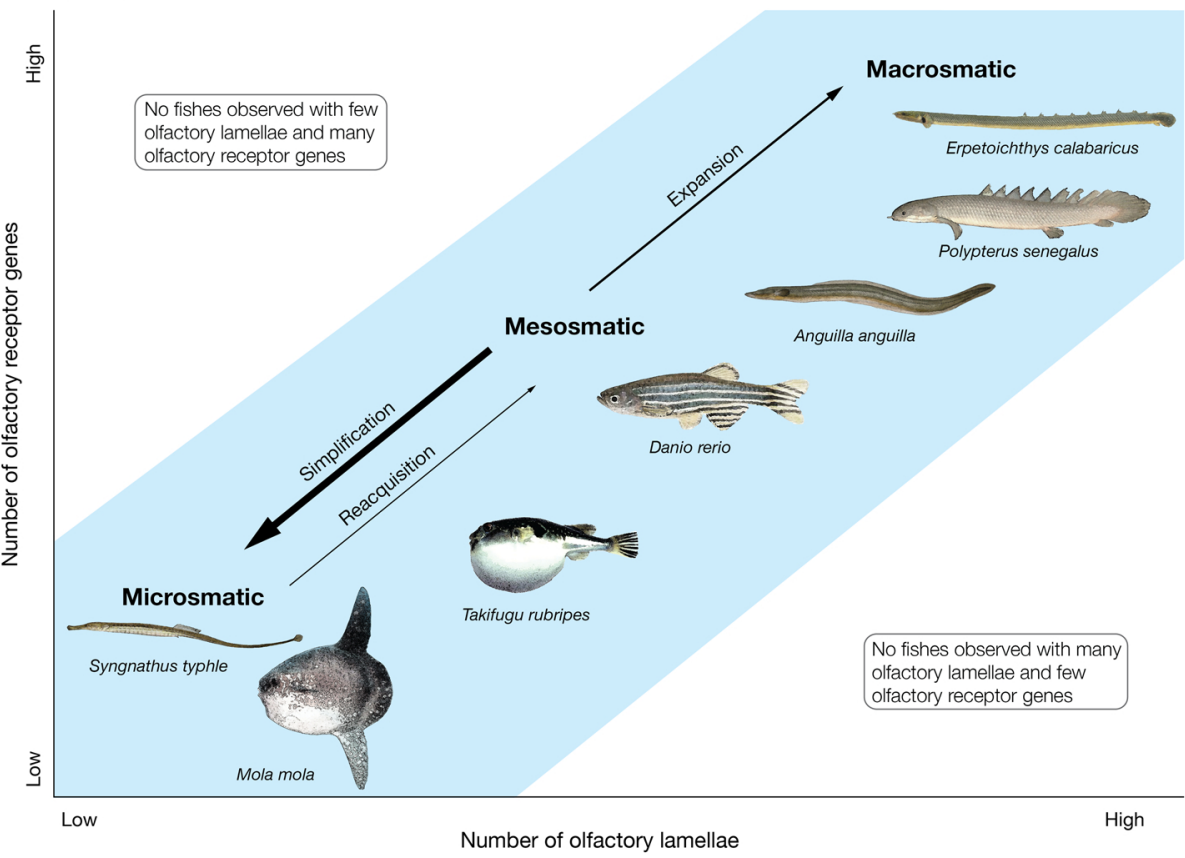

Figure 2 

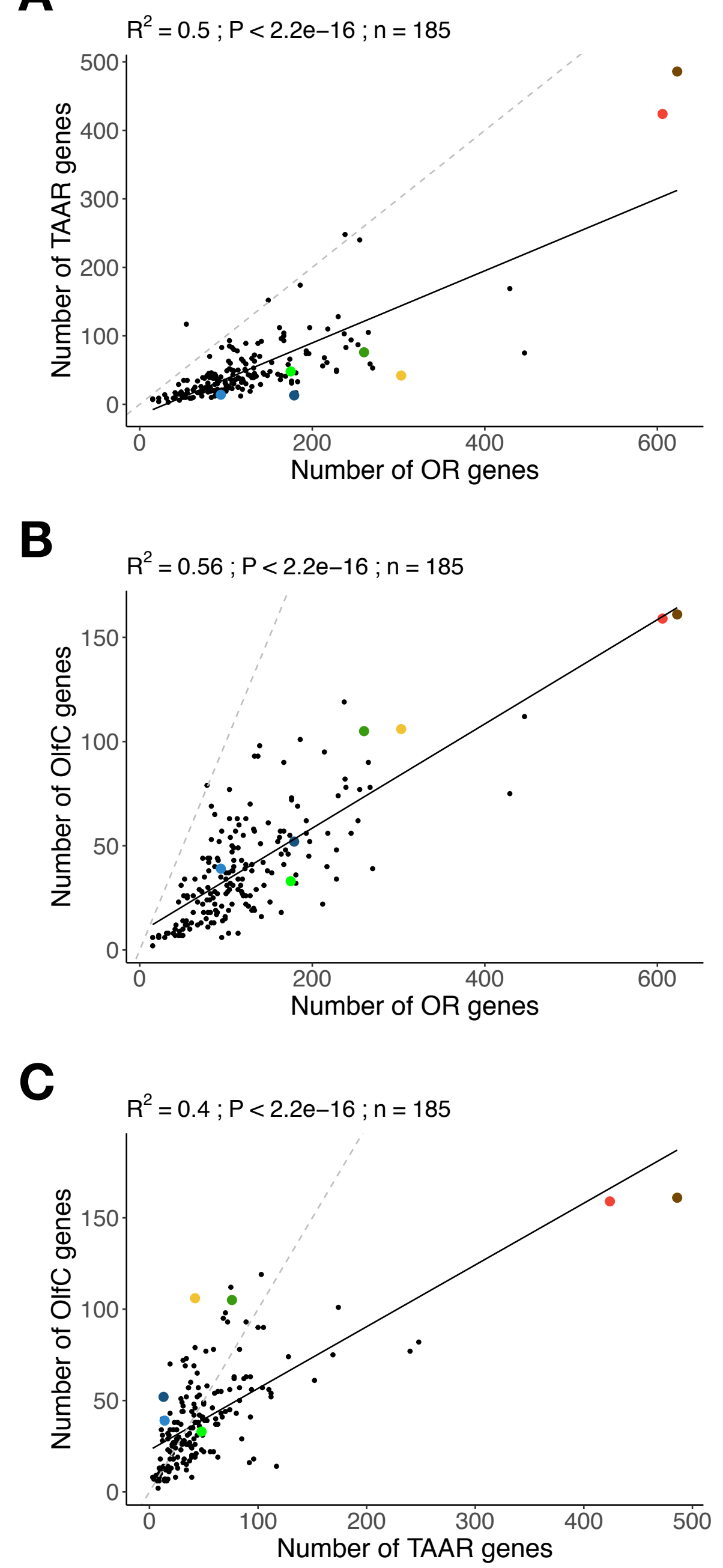

Figure 3 

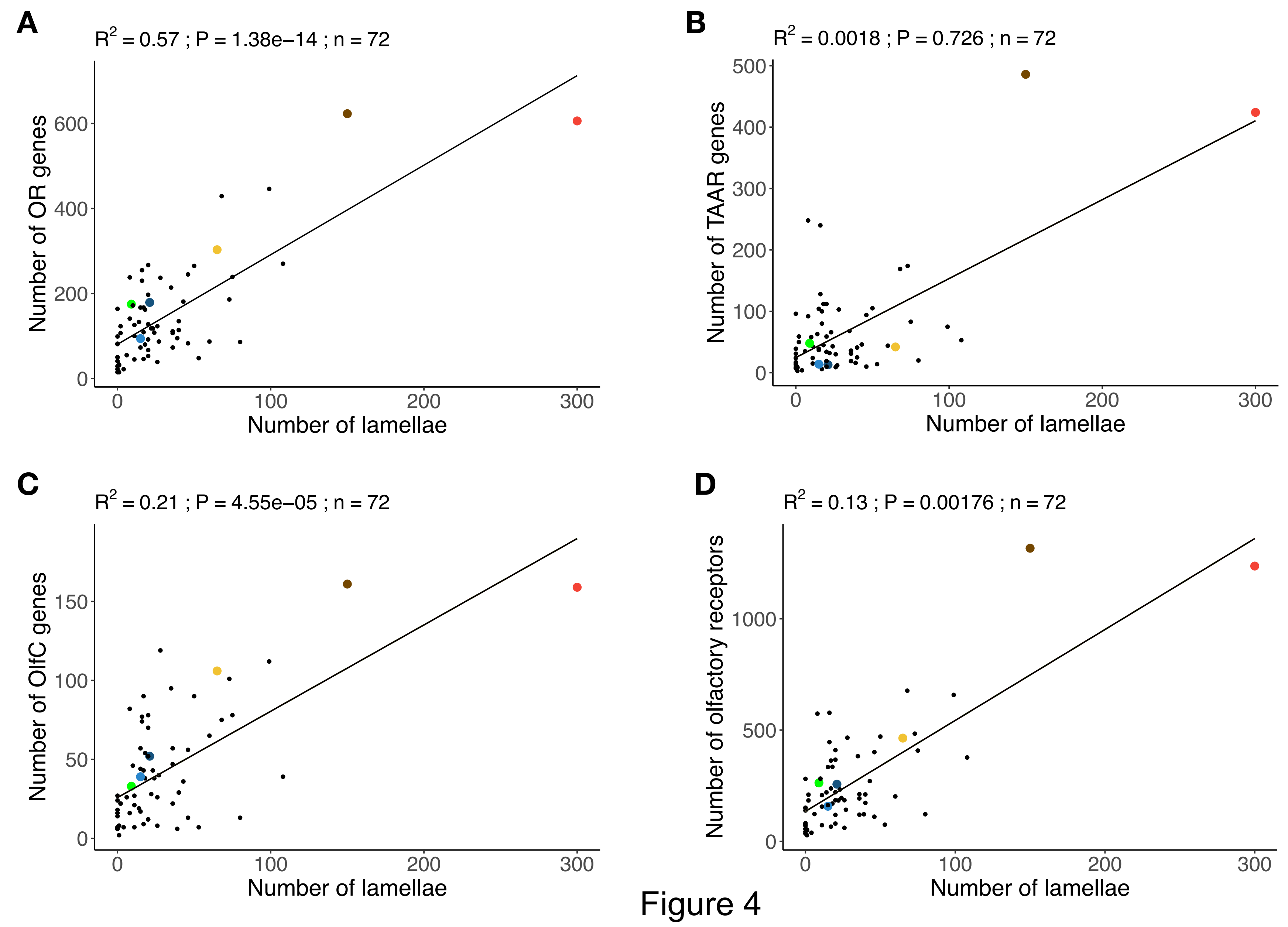


\section{Materials and Methods}

\section{Olfactory epithelium data}

We surveyed the literature on olfactory organs in fishes and found data on number of lamellae for 60 species for which a draft genome assembly was available. We also dissected the olfactory organ and made lamellae counts for 12 species at the National Museum of Natural History, Washington, DC USA. Literature and specimen data were collected from adults because the number of lamellae often increases with total length (TL); we did not consider sexual dimorphism or individual age, which can impact number of olfactory lamellae ${ }^{1,31}$. We classified the olfactory epithelium as flat if it had $\leq 2$ lamellae and multilamellar if it had $>2$ lamellae following Hansen et al. (2005) ${ }^{4}$. Olfactory lamellae data used in the analyses is summarized in Supplementary data 1.

374 Using BUSCO (v5.2.2) ${ }^{32}$, high quality genomes of 185 ray-finned fishes were selected, 375 including 178 teleost genomes with a BUSCO score $>90 \%$ and seven non-teleost genomes 376 with BUSCO score ranging from $81 \%$ to $93 \%$ (Supplementary data 1).

377 A time-calibrated phylogenetic tree of ray-finned fishes was downloaded from

$378 \mathrm{https}$ ://fishtreeoflife.org ${ }^{7}$ and pruned using the R package ape (v5.0) ${ }^{33}$ to the 185 species 379 included in our study.

380 Single-exon genes that code for OR receptors were mined following methods described by 381 Policarpo et al. (2021) ${ }^{13}$. TAAR, OlfC and ORA genes, which consist of several exons, were 382 identified following Azzouzi et al. (2015) ${ }^{34}$, with slight modifications. In brief, a TBLASTN 
${ }^{35}$ was performed using known TAAR, OlfC or ORA sequences as queries with a threshold e-

384 value $<1 \mathrm{e}-10$ to select regions containing putative TAAR, OlfC or ORA genes. Non-

overlapping hit regions were extracted and extended 5000 bp upstream and downstream using

SAMtools ${ }^{36}$. For each extended non-overlapping hit region, the protein with the best

TBLASTN match was aligned to the DNA sequence using EXONERATE (v2.2) ${ }^{37}$ and the

388 resulting protein-coding sequence was used as query for a BLASTX against a custom

389 database of OR, TAAR, OlfC, ORA and other G protein-coupled receptors (GPCRs). Protein-

390 coding sequences that best matched TAAR, OlfC or ORA receptors were retained and

391 manually curated. Each protein-coding sequence was translated and aligned to known

392 olfactory receptors and other GPCR genes with MAFFT (v7.487) ${ }^{38}$ and maximum likelihood

393 trees were computed with IQ-TREE (v1.6.12) ${ }^{39}$. Only protein-coding sequences that

394 clustered with known olfactory receptors by visual inspection using iTOL ${ }^{40}$ were retained as

395 olfactory receptor genes. When several identical sequences were retrieved in a genome, only

396 one was kept using CD-HIT ${ }^{41}$.

397 Retrieved coding sequences were classified as: 1) 'gene' if complete and without loss-of-

398 function mutation (premature stop codon or frameshift), 2) 'pseudogene' if complete and with

399 at least one loss-of-function mutation, 3) 'truncated' if incomplete and without loss-of-

400 function mutation, 4) 'edge' if incomplete and less than $30 \mathrm{bp}$ from a contig border.

401 We assessed the quality of our mining pipeline by comparing the olfactory gene repertoires

402 we identified with those published by other authors for four teleost species. We systematically

403 found more genes than previous studies, in particular, in P. senegalus, we identified three

404 times more OR genes (Supplementary data 2). 
For each species, we aligned protein sequences coded by putative OR genes with known OR genes $^{22}$ using MAFFT. A maximum likelihood tree was computed with IQ-TREE and genes were classified according to their position in the tree. To assess the relative diversity of OR

411 subfamilies, a phylogenetic tree with OR genes of 44 species, each species belonging to a

412 different order based on fishtreeoflife (https://fishtreeoflife.org/), was computed. The root was

413 placed between Type I and Type II genes (Supplementary data 3). Using MAFFT, putative

414 TAAR genes were aligned with TAARs and non-TAAR GPCRs genes obtained from Dieris

415 et al. (2021) ${ }^{42}$. A maximum likelihood tree was computed with IQ-TREE and genes were

416 classified according to their position in the phylogenetic tree (Supplementary data 3). The

417 same method was used for putative OlfC and ORA genes. For putative OlfC genes, we used 418 genes from Yang et al. (2019) ${ }^{19}$ and CasR and V2R2 genes as outgroups (Supplementary

419 data 3). For ORA sequences, we used genes from Zapilko et al. (2016) ${ }^{18}$ and T2R genes as 420 an outgroup (Supplementary data 3 ).

421 Pseudogenes, truncated genes and edge gene classification was based on the best blastx 422 match.

We estimated phylogenetic signal (Pagel's $\lambda$ ) of each trait with the function phylosig in the R

427 package phytools with the option test $=$ TRUE $^{43}$. The R package caper (v1.0.1) ${ }^{44}$ was used to 428 perform phylogenetic generalized least square analyses using the function "pgls" with lambda $429=$ "ML" (Supplementary data 1). 
433 The number of gene gains and number of gene losses along each branch of the species

434 phylogenetic tree were inferred using the gene tree - species tree reconciliation method. The

435 OR family is large, as described previously ${ }^{13}$, and thus OR genes belonging to different

436 subfamilies were aligned separately. For the smaller TAAR, OlfC and ORA gene families,

437 one alignment was obtained for each gene family separately. All alignments were obtained

438 using MAFFT. Maximum likelihood trees were computed with IQ-TREE. Nodes with low

439 bootstrap values $(<90 \%)$ were collapsed into polytomies using the R package ape. We then

440 used Treerecs ${ }^{23}$ to root and reconcile genes trees with the species tree.

441 For each olfactory receptor family, we computed birth and death rates using equations in

442 Niimura et al. (2014) ${ }^{45}$ excluding branches with length $<2$ Mya because differences in gene

443 retrieval and genome qualities greatly impacted inferred birth and death rate ${ }^{13}$.

\section{Data availability}

All sequences extracted in this study are available on

https://figshare.com/articles/dataset/Olfactory_receptor_sequences_for_185_ray-

449 finned_fishes/17061632.

453 Supplementary data 1. Sheet 1: NCBI Assembly accession and assembly level of the 185

454 genomes studied, their species name in NCBI and in Eschmeyer's Catalog of Fishes. Sheet 2:

455 results of BUSCO analyses on the 185 genomes studied. Sheet 3: species' name and order

456 based on the taxonomy of fishtreeoflife.org. Sheet 4: summary of the number of genes in each

457 olfactory receptor family for every species. Sheet 5: Olfactory epithelium shape and number 
of lamellae in 72 ray-finned fishes for which a genome assembly is available. Sheet 6 :

459 phylogenetic signal of the number of gene in each family and of the number of lamellae in the epithelium computed with phytools. Values of phylogenetic regression described in this study are also given.

Supplementary data 2. Comparison of olfactory receptor gene repertoires from the present and previous studies. (A) Summary of the number of TAAR genes retrieved in our study and previous studies of four teleost species. (B) Summary of the number of OlfC genes retrieved in our study and previous studies of four teleost species. (C) Summary of the number of ORA genes retrieved in our study and previous studies of four teleost species. (D) Phylogenetic tree of Danio rerio TAAR genes retrieved in Hashiguchi and Nishida 2007 and our study. (E) Phylogenetic tree of Gasterosteus aculeatus TAAR genes retrieved in Azzouzi et al. 2015 and our study. (F) Phylogenetic tree of Oryzias latipes TAAR genes retrieved in Azzouzi et al. 2015 and our study. (G) Phylogenetic tree of Takifugu rubripes TAAR genes retrieved in Hashiguchi and Nishida 2007 and our study. (H) Phylogenetic tree of Danio rerio OlfC genes retrieved in Yang et al. 2019 and our study. (I) Phylogenetic tree of Gasterosteus aculeatus OlfC genes retrieved in Yang et al. 2019 and our study. (J) Phylogenetic tree of Oryzias latipes OlfC genes retrieved in Yang et al. 2019 and our study. (K) Phylogenetic tree of Takifugu rubripes OlfC genes retrieved in Yang et al. 2019 and our study. (L) Phylogenetic tree of Danio rerio ORA genes retrieved in Zapilko and Korsching 2016 and our study. (M)

478 Phylogenetic tree of Gasterosteus aculeatus ORA genes retrieved in Zapilko and Korsching 4792016 and our study. (N) Phylogenetic tree of Oryzias latipes ORA genes retrieved in Zapilko and Korsching 2016 and our study. (O) Phylogenetic tree of Takifugu rubripes ORA genes

481 retrieved in Zapilko and Korsching 2016 and our study. (P) Phylogenetic tree of Polypterus 482 senegalus OR genes retrieved in Bi X et al. 2021 and our study. 
Supplementary data 3. (A) Phylogeny of OR genes from 44 species representing 44 orders of ray-finned fishes sampled in this study. Branches are colored according to the gene subfamily classification. (B) Phylogeny of all TAAR genes retrieved from 185 ray-finned fishes.

Branches are colored according to gene family classification. Outgroup sequences (nonTAAR

Outgroup sequences (T2R genes) are colored in black.

\section{Acknowledgments}

This work was supported by a collaborative grant from Institut Diversité Ecologie et

498 Evolution du Vivant (to S.R. and D.C).

499 M.P. was supported by a PhD fellowship from the French Ministry of Research.

$500 \mathrm{~J}$. Galbraith provided the examined specimen of Mola mola.

501

\section{Author Contributions}

503

504 M.P., K.B., S.R and D.C. conceptualized the project. M.P. carried out phylogenetic and 505 statistical analyses. K.B. obtained morphological data. P.L. produced fish drawings. P.L., 506 L.L., J.-C.S. and S.R. contributed to data analyses. D.C. supervised phylogenetic and 
507 statistical analyses. M.P. and K.B made the figures. D.C., M.P. and K.B. wrote the

508 manuscript. All authors commented on the manuscript and agreed to its final version.

509

510 Competing interests

511 The authors declare no competing interests.

512 


\section{Materials and Methods references}

51531 Abrahão, V. P., Pastana, M. \& Marinho, M. On a remarkable sexual dimorphic trait in the Characiformes related to the olfactory organ and description of a new miniature species of Tyttobrycon Géry (Characiformes: Characidae). PLOS ONE 14, e0226130 (2019).

Waterhouse, R. M. et al. BUSCO applications from quality assessments to gene prediction and phylogenomics. Molecular Biology and Evolution 35, 543-548 (2018). Genomics 16, 335 (2015). 421 (2009).

Li, H. et al. The Sequence Alignment/Map format and SAMtools. Bioinformatics 25, 2078-2079 (2009).

53037 Slater, G. S. C. \& Birney, E. Automated generation of heuristics for biological sequence comparison. BMC Bioinformatics 6, 31 (2005). 772-780 (2013).

53539 Nguyen, L.-T., Schmidt, H. A., von Haeseler, A. \& Minh, B. Q. IQ-TREE: A fast and effective stochastic algorithm for estimating maximum-likelihood phylogenies. 
$53840 \quad$ Letunic, I. \& Bork, P. Interactive Tree Of Life (iTOL): an online tool for phylogenetic

539 tree display and annotation. Bioinformatics 23, 127-128 (2007).

54041 Fu, L., Niu, B., Zhu, Z., Wu, S. \& Li, W. CD-HIT: Accelerated for clustering the next541 generation sequencing data. Bioinformatics 28, 3150-3152 (2012).

54242 Dieris, M., Kowatschew, D. \& Korsching, S. I. Olfactory function in the trace amineassociated receptor family (TAARs) evolved twice independently. Scientific Reports 11, 7807 (2021).

$54543 \quad$ Revell, L. J. phytools: an R package for phylogenetic comparative biology (and other 546 things). Methods in Ecology and Evolution 3, 217-223 (2012).

54744 Orme, D. et al. Caper: comparative analyses of phylogenetics and Evolution in R. R package version 1.0.1. https://CRAN.R-project.org/package=cape (2018).

54945 Niimura, Y., Matsui, A. \& Touhara, K. Extreme expansion of the olfactory receptor gene repertoire in African elephants and evolutionary dynamics of orthologous gene groups in 13 placental mammals. Genome Research 24, 1485-1496 (2014). 


\section{Legends Extended data}

556 Extended data Fig. 1. Diversity of the olfactory receptor gene repertoire in ray-finned fishes.

557 Time-calibrated phylogeny from https://fishtreeoflife.org/. (A) For each species, a multiple values barplot represents the number of functional genes, pseudogenes, truncated and edge

560 available, the olfactory epithelium shape and the number of lamellae is indicated. Inferred

561 numbers of gene gains and losses are provided on branch of the trees. Whole-genome

562 duplications are indicated by red stars. The branches associated with the three highest death

563 rates and the two highest birth rates of the OR, TAAR and OlfC families are indicated by

564 circles and diamonds, respectively, with color code as in Fig. 1. The trees were annotated and 565 visualized using iTOL.

567 Extended data Fig. 2. Distribution of ORA7 and ORA8 subfamilies in ray-finned fishes.

568 Time-calibrated phylogeny from https://fishtreeoflife.org/. (A) ORA7, (B) ORA8.

Extended data Fig. 3. Distribution of birth and death rates of OR, TAAR, and OlfC genes in

ray-finned fishes. $\bar{\beta}$ : mean birth rate; $\bar{\delta}$ : mean death rate. The two highest birth rates and the

572 three highest death rates are indicated by colored arrows. Arrow colors correspond to the colors of circles and diamonds in Fig. 1 showing branches with high birth and death rates.

575 Extended data Fig. 4. Correlation of the number of gene losses (or gene gains) between gene

576 families, estimated using the 368 branches of the phylogenetic tree. (A,D) Correlations

577 between OR and TAAR families; (B,E) correlations between OR and OlfC families; (C,F)

578 correlations between TAAR and OlfC families. 
580 Extended data Fig. 5. Correlation between the number of OR, TAAR and OlfC pseudogenes

581 in 185 ray-finned fishes. (A) Phylogenetic generalized linear regression (Pagel's $\lambda$ model)

582 between the number of OR and TAAR pseudogenes, (B) OR and OlfC pseudogenes, (C)

583 TAAR and OlfC pseudogenes. (D) Phylogenetic generalized linear regression (Pagel's $\lambda$

584 model) between the proportion of OR and TAAR pseudogenes, (E) OR and OlfC

585 pseudogenes, (F) TAAR and OlfC pseudogenes. The coefficient of determination (R2), the p-

586 value (P) and the regression line (solid line) of PGLS analyses are reported. Dotted line: slope

$587=1$. Dot color code: as in Fig. 1.

589 Extended data Fig. 6. Narial tubes of four species of ray-finned fishes with complex olfactory

590 organs and large gene repertoire. (A) Erpetoichthys calabaricus; photograph by Katherine E.

591 Bemis, NOAA National Systematics Lab. (B) Polypterus senegalus, photograph by Basal

592 Zoo. (C) Representative Anguillidae, Anguilla japonica, photograph by unknown. (D)

593 Mastacembelus armatus, photograph by Zach Randall, Florida Museum of Natural History.

595 Extended data Fig. 7. Takifugu rubripes, USNM 57620, 290 mm TL. (A) Bridge of tissue

596 between excurrent and incurrent nares. (B) Bridge of tissue cut and reflected to show lamellae

597 in olfactory organ. Note that lamellae are not arranged in a rosette, but parallel to each other

598 in a circle under the bridge and over the floor of the olfactory organ. 


\section{A}

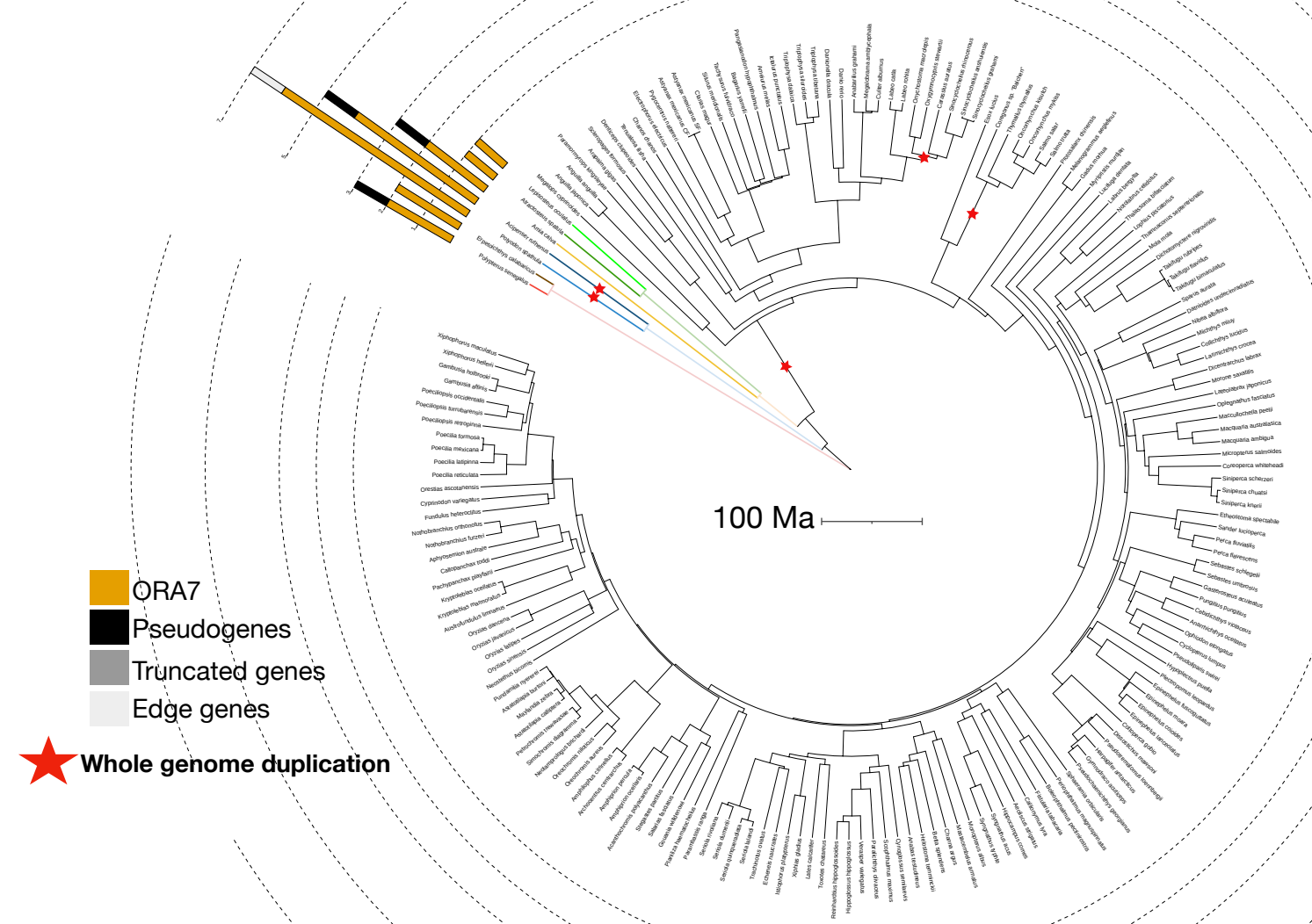

B

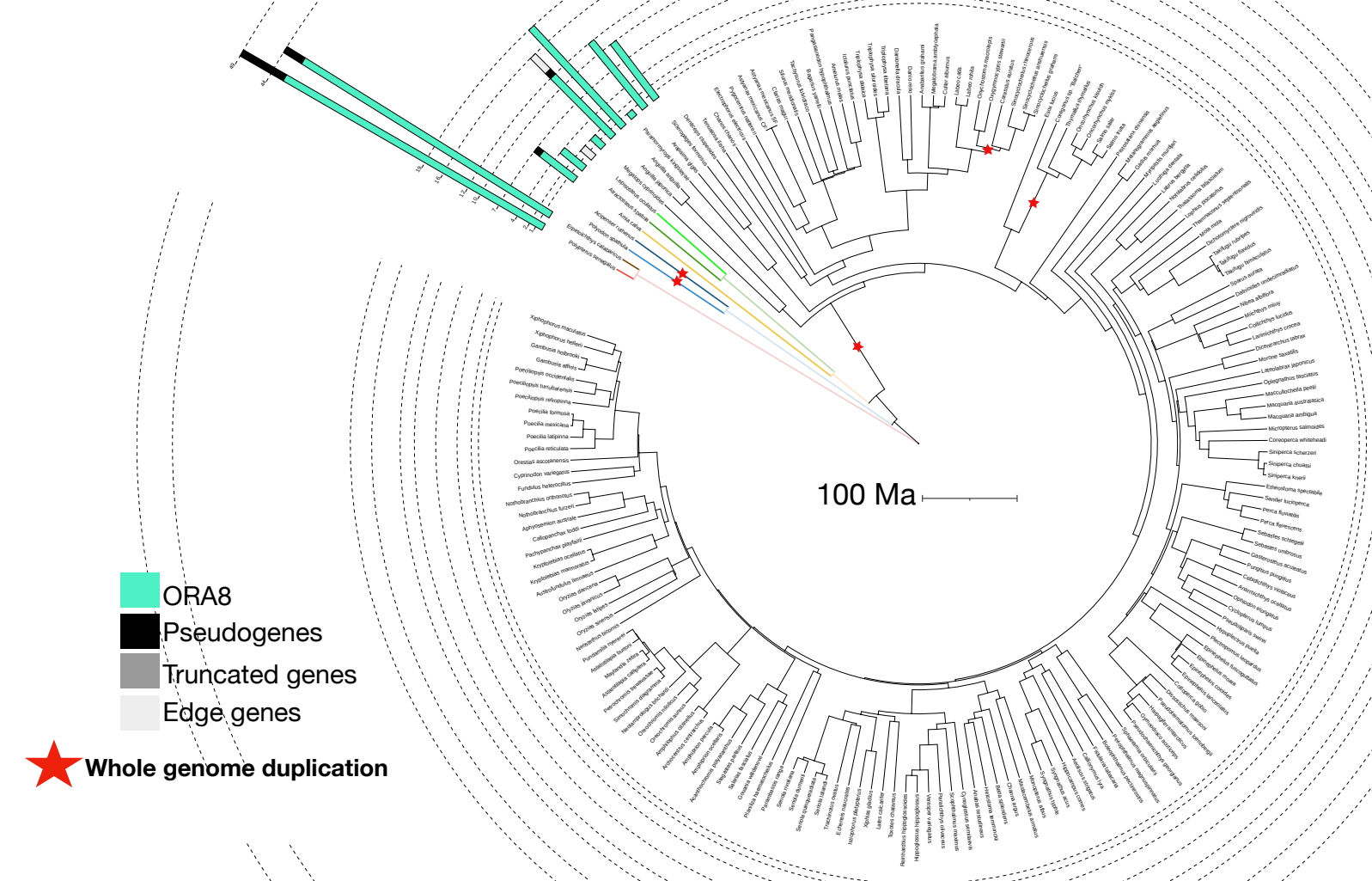



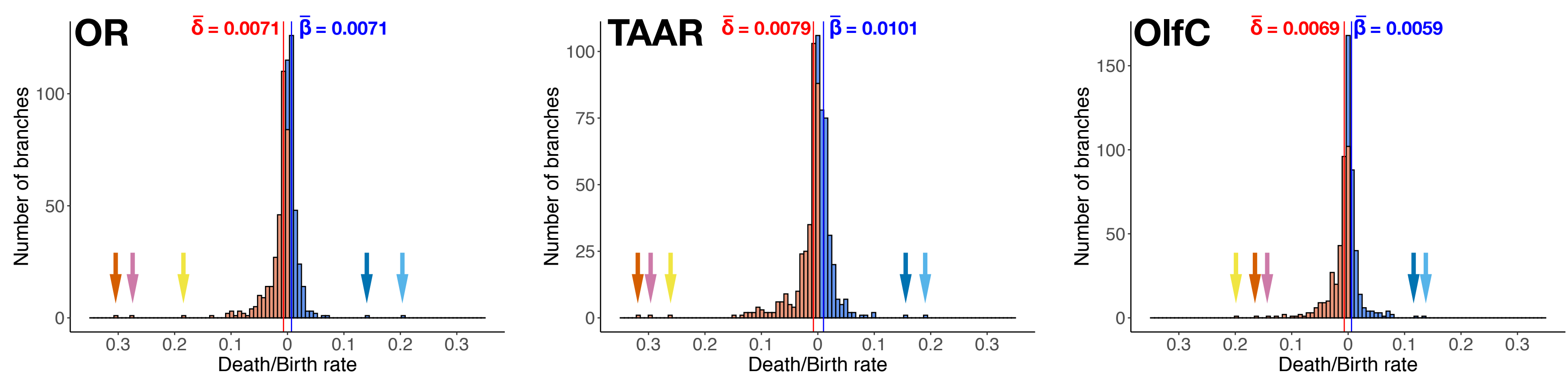

Extended data Figure 3 
A

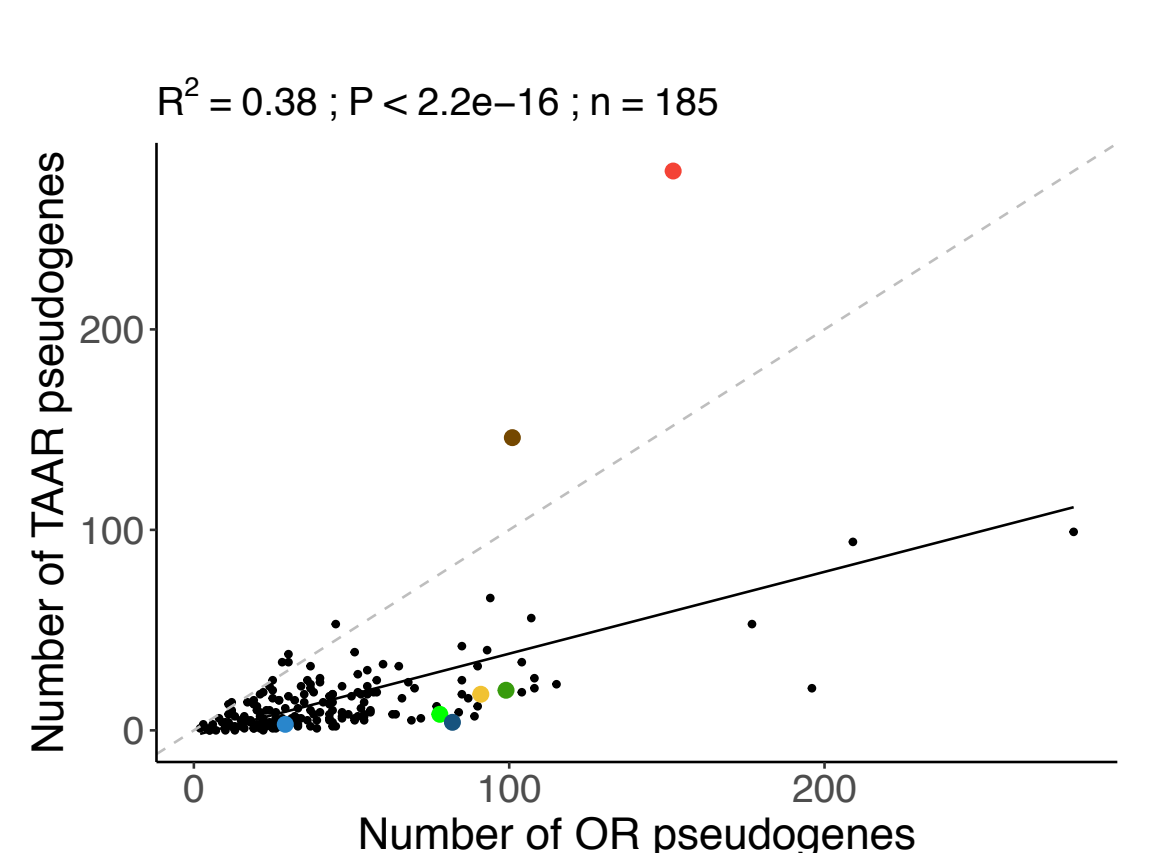

B

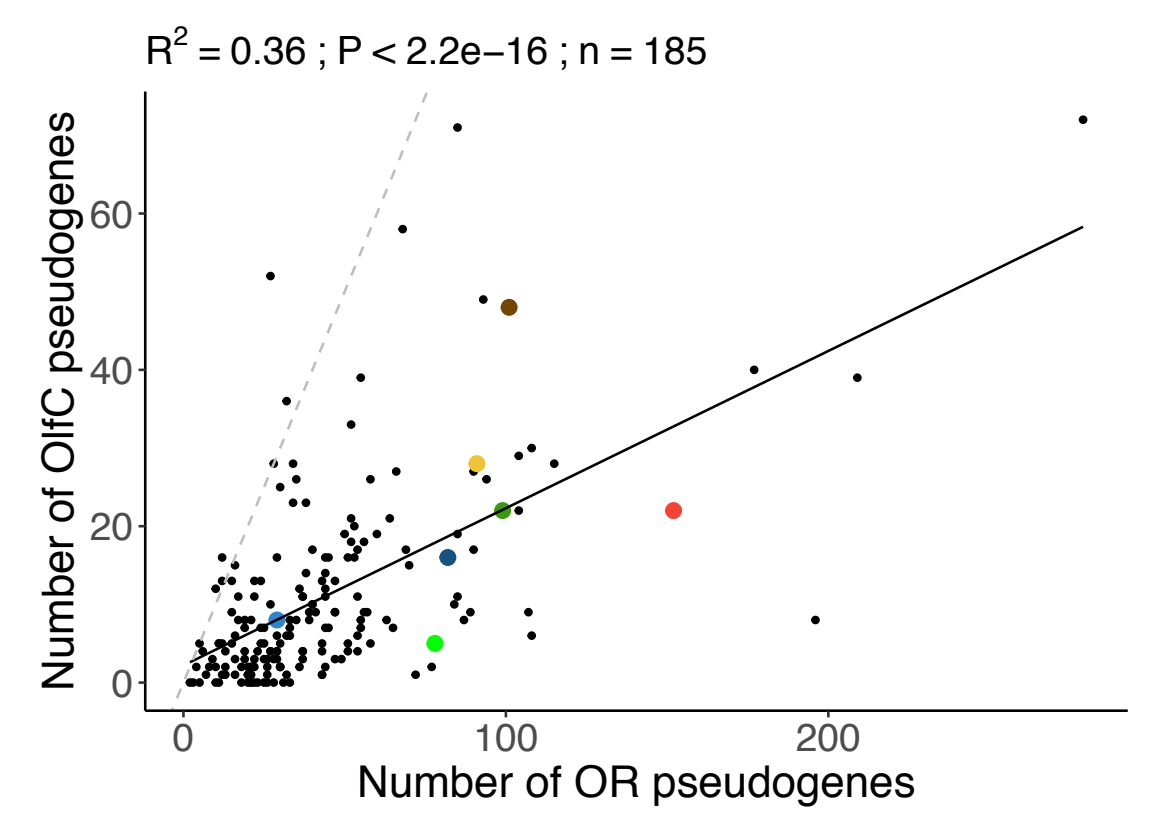

C

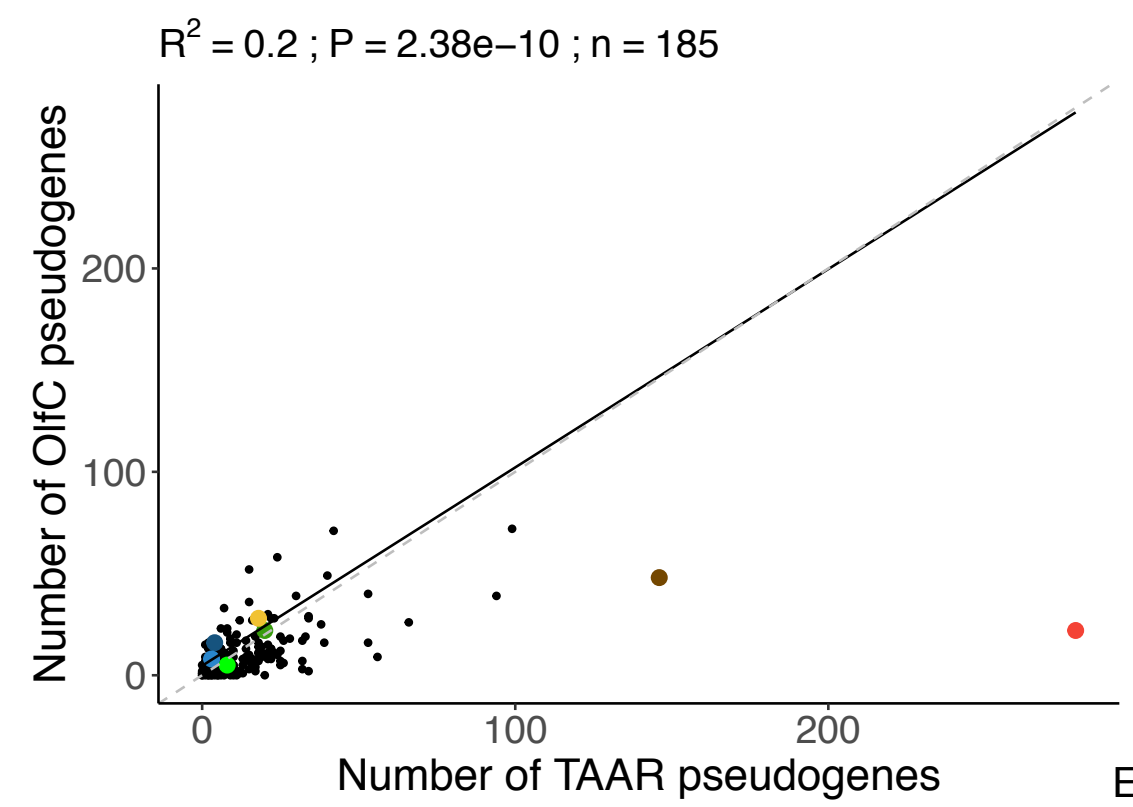

D

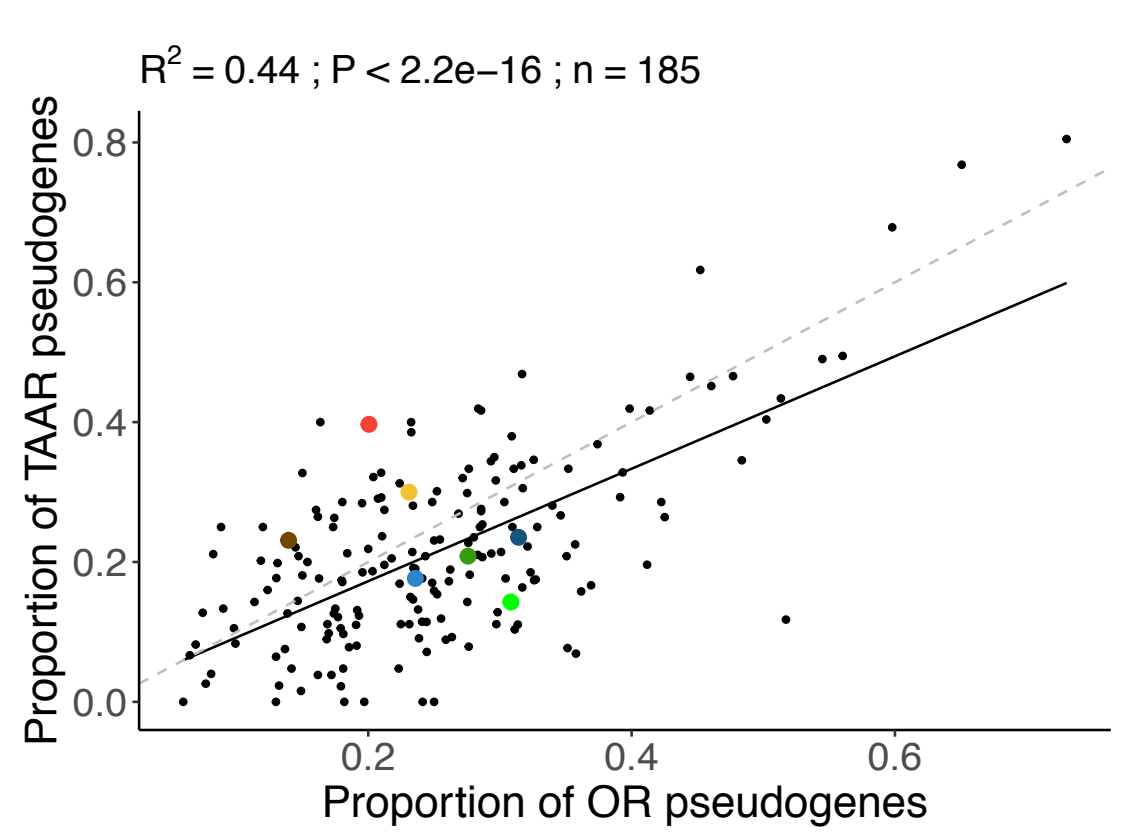

E

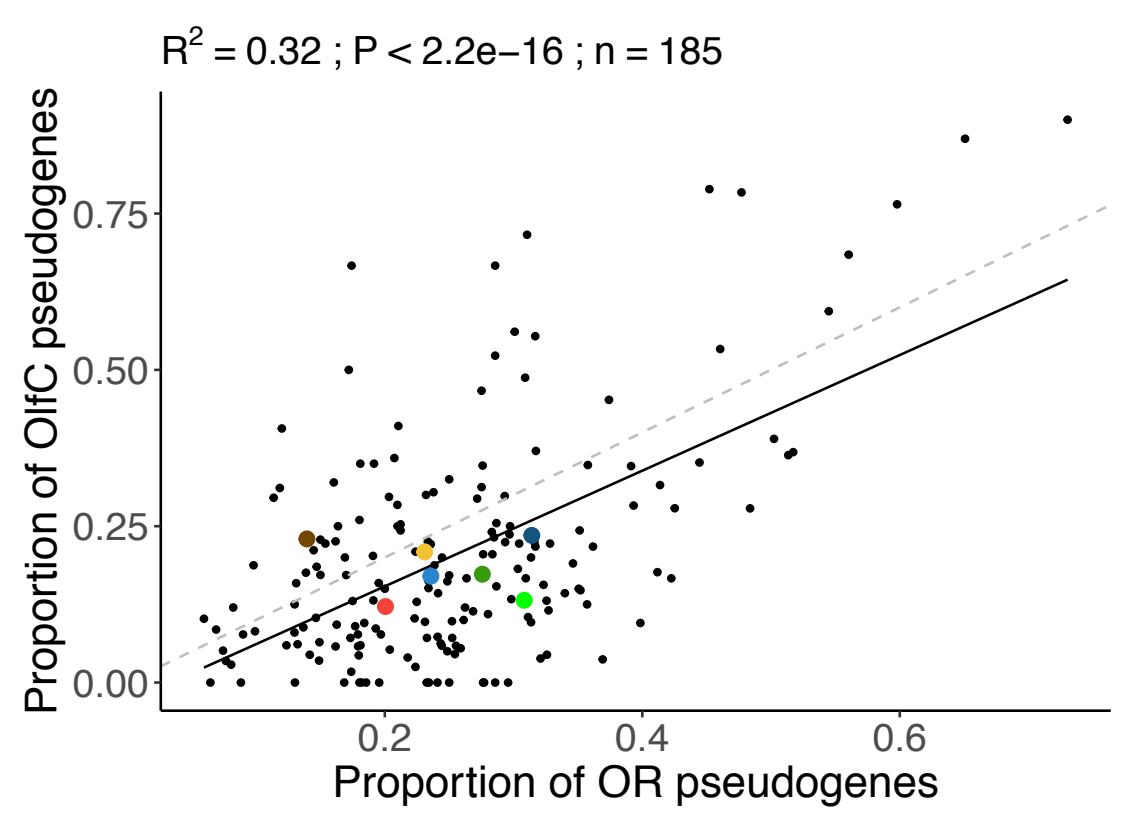

F

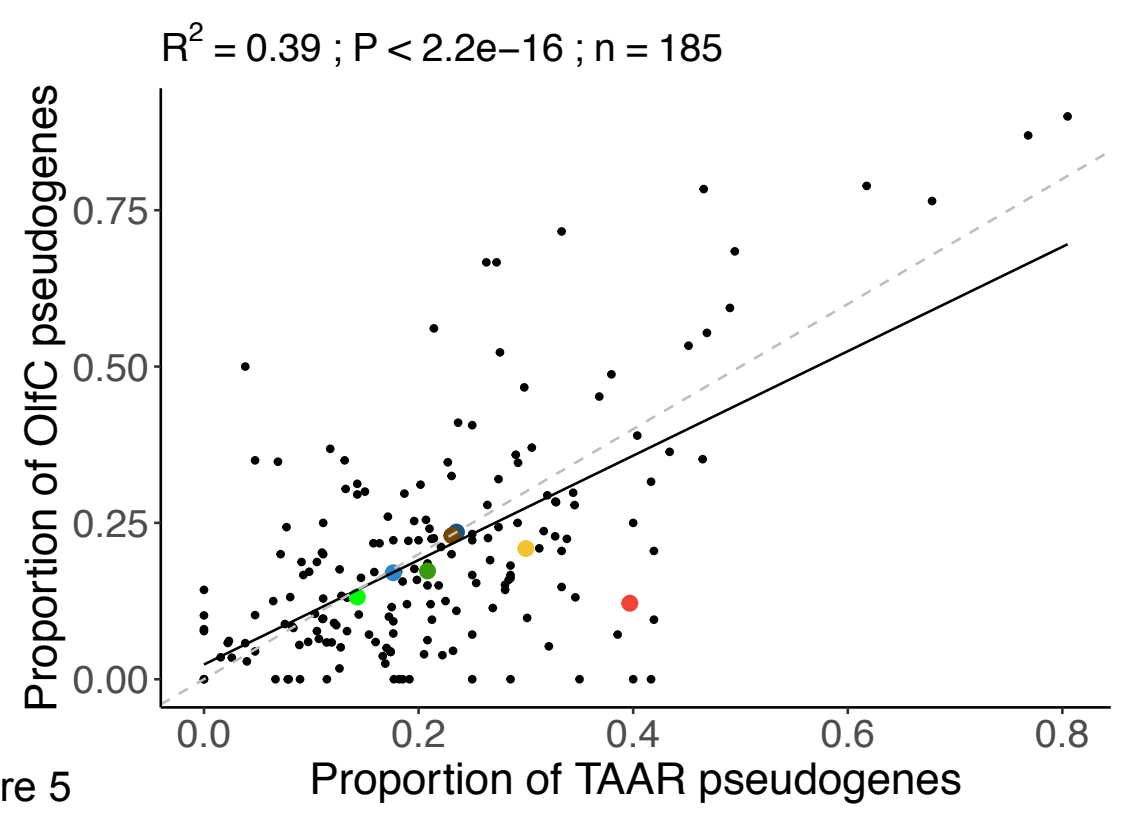



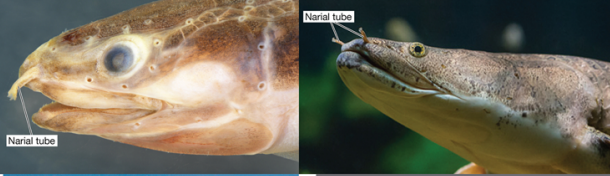

c

D

Narial tube

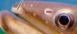

1.5

(5x)

Narial tube

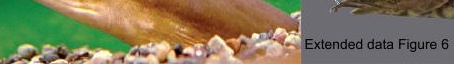

Narial tube
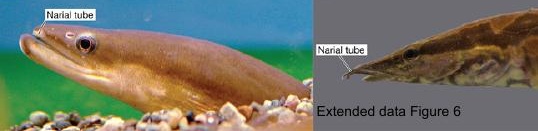


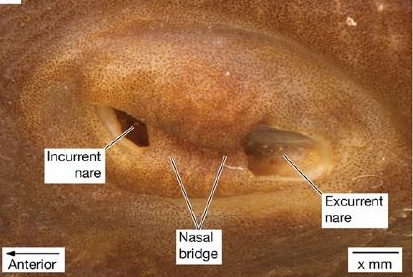

\section{B Cut and reflected nasal bridge}
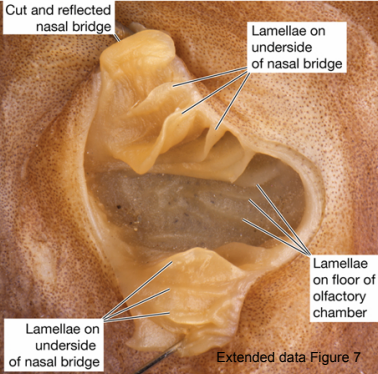

amelae on underside 